\title{
COMPARISON STUDY ABOUT DETERMINANTS OF CHILDREN UNDER FIVE YEARS MALNUTRITION BETWEEN INDIGENOUS AND NON-INDIGENOUS COMMUNITIES IN INDONESIA
}

\author{
Rahmah Hida Nurrizka ${ }^{1 *}$, Dwi Mutia Wenny ${ }^{1}$ and Agustina ${ }^{1}$ \\ ${ }^{1}$ Department of Public Health, Faculty of Health Science, Universitas Pembangunan Nasional (UPN) “Veteran” Jakarta- \\ Indonesia
}

Corresponding author: Rahmah Hida Nurrizka

Email: rh.nurrizka@upnvj.ac.id

\begin{abstract}
Many studies reveal the determinant factor of children under five years of malnutrition problem in Indonesia. However, there is only a few analysis conducted on indigenous communities and its comparison to non-indigenous communities. This study analyzes the determinant factors of malnutrition in children under five years in indigenous communities (Suku Baduy) and non-indigenous communities. This study is a comparative study using cross-sectional data, where the samples are households that have children under five years in indigenous communities $(n=60)$ and in non-indigenous communities $(n=60)$, with sample techniques using purposive random sampling. To calculate nutrition status, this study uses the anthropometric index based on weight-for-age according to WHO standards presented in the Z-score and Standard Deviations (SD). The result of this study indicates that the prevalence of children under five years suffering from malnutrition in indigenous communities is lower than in non-indigenous communities, which is $21,7 \%$ to $43,3 \%$. Two factors influence the high prevalence of malnutrition in children under five years, namely, the education of the head of a family with OR=0.120 (95\%C1: 0.021-0.675) and prenatal care in the fourth trimester with OR 9.890 (95\%C1: 1.349-72.531). It is necessary to increase public knowledge on balanced nutrition in children under five years and improved maternal health access to resolve children under five years of malnutrition in those communities.
\end{abstract}

Keywords: malnutrition, anthropometric index, Suku Baduy, Indonesia

\section{INTRODUCTION}

Indonesian children still suffer from malnutrition $^{1,2}$. Data from the Ministry of Health Republic of Indonesia in 2018 shows that there were $30,8 \%$ of Indonesian children under five years suffering from stunting and $10,2 \%$ from wasting ${ }^{3}$. Although the figure has decreased compared to 2013, the prevalence is still high when compared to several Southeast Asian countries such as Singapore $(4,4 \% ; 3,6 \%)^{4}$, Thailand $(10,8 \% ; 5,4 \%)^{5}$, Brunei Darussalam $(19,7 \% ; 2,9 \%)^{6}$, Malaysia $(20,7 ; 11,5 \%)^{7}$, and Vietnam $(24,6 \% ; 6,4 \%)^{8}$.

Three main problems cause the high prevalence of malnutrition in Indonesia. First, unequal public access to health services. The inequality occurs between cities and villages, western and eastern parts of Indonesia, as well as in intercommunity, such as the indigenous community and nonindigenoues community. This condition causes interventions to improve nutrition for children under five in curative, preventive, and promotive measures difficult particularly in areas and communities where health facilities are limited. In fact, in many studies, limited access to health services increases the risk of malnutrition on childrens ${ }^{9,10}$.

Secondly, the low level of public knowledge regarding balanced nutrition. Although food availability is relatively good in Indonesia, people have yet acquired adequate knowledge of balanced nutrition. Thus, intakes and food patterns do not meet the criteria of quality nutrition. This happens from pregnancy until infants aged two years old, whereas the first 1000 days of life is pivotal in children's growth and development as well as life quality in the future ${ }^{11}$. In this case, parents hold an important role in meeting the nutrition intakes of their children under five years ${ }^{12}$. Parents who lack knowledge of quality nutrition are prone to raising children under five years with malnutrition risk ${ }^{13-15}$.

Thirdly, poor and uneven environment quality. Digestion and respiratory tract infections on infants from bacterial and viral contamination is a direct result of malnutrition ${ }^{16,17}$. This is the outcome of a bad environment where children grow, such as poor sanitation, low access to clean water, air pollution, and trash pollution ${ }^{18,19}$. Unfortunately, many Indonesian children are still living under such environmental conditions, not only in rural but also in urban areas.

However, indigenous communities need more attention as they are vulnerable and are often marginalized in health development. There are 538 indigenous communities in Indonesia ${ }^{20}$ whose conditions are very vulnerable to health development. They mostly live in forest areas far 
from access to health services, one of which is Suku Baduy.

Suku Baduy lives in the forest and is still upholding their ancestral tradition and culture, which is to preserve nature ${ }^{21}$. They strongly believe in nature-related magical power and refuse modernization. The community is prohibited from using electricity, television, vehicles, and other technologies, for instances 22,23 . Suku Baduy is known as traditional farmers who never experience food shortage, let alone hunger ${ }^{21}$.

In Indonesia, there are not many studies that have analyzed the problem of malnutrition in children under five years in indigenous peoples, despite its importance as monitoring measures to improve the quality of children under five years of health in indigenous peoples. This study was prepared in response to the lack of research related to the nutritional status of children under five years in Indonesia's indigenous communities, with Suku Baduy as object research.

This study aimed at analyzing determinant factors of children under five years of malnutrition in indigenous communities and non-indigenous communities. The determinant factors analyzed in this study are household's social-demographic conditions, children under five years nutritional intakes, household access to health service and household environment condition.

\section{METHODS}

\section{Study Design}

This study is a comparative study using crosssectional data. This study compares the determinants of malnutrition among children under five years in indigenous communities and urban communities in Indonesia. The indigenous communities that is the sample of this study is Suku Baduy. Meanwhile, the non-indigenous communities which is the comparison is the urban communities, by selecting one more community that has different characteristics with Suku Baduy. This research looks at an urban communities located in the same district as Suku Baduy.

\section{Study Location}

Two locations are subject of this study. First, Kanekes Villages located in Leuwidamar Subdistrict, Lebak, Banten Province, Indonesia. The village is home to Suku Baduy. The second location took place in Rangkasbitung Barat and Rangkasbitung Timur of Rangkasbitung Subdistrict, Lebak District, Banten Province, Indonesia. Both villages are representatives of non-indigenous communities.

\section{Sample of Study}

The sample in this study is households with children under five years. The sampling technique conducted with purposive random sampling. There is a total of 120 households with sample distribution as follows, 60 households from indigenous communities (Suku Baduy) and 60 households from non-indigenous communities or urban communities.

\section{Instruments and Indicators}

There are five instruments used in the data collection. First, the instrument for measuring children under five years of nutritional status using the anthropometric index, which is measured by weight-for-age. Second, questionnaire on household's social-demographic conditions, with variables consisting of children under five years sex, number of family members, work of the head of the family, education of the head of the family, and age of the head of the family, as well age of mother and education of the mother. Third, questionnaire on children under five years nutritional intakes, with variables consisting of getting exclusive breastfeeding and complementary feeding; vitamin A intakes; vegetable consumption in the last one week; fruits consumption in the last one week; protein consumption in the last one week; and carbohydrate consumption in the last one week. Fourth, questionnaire on household access to health service, with variables consisting of complete immunization; routine prenatal care in first, second, third, and fourth trimesters; maternal iron intake; and childbirth assistant. Fifth, questionnaire on household environment condition, with variables consisting of drinking water source and sanitation type.

\section{Method of Measurement and Analysis}

We assessed nutritional status in children under five years by utilizing the anthropometric index based on the ratio between body mass and age. This index was derived from the WHO standard with Z-score and standard deviation (SD). A child would be considered having malnutrition if the anthropometric index was Z-score < -3.0 SD, under-nutrition if it was Z-score of -3.0 to $<-2.0$ SD, normal if it was Z-score of -2.0-2.0 SD, and over nutrition, if it was $>2.0 \mathrm{SD}^{24}$. The analysis in this study used univariate, bivariate, and multivariate analysis.

\section{Ethical considerations}

This research was granted permission by the Lebak District Government and Universitas Pembangunan Nasional (UPN) Veteran JakartaIndonesia. All respondents have explained the objectives of the study and secured written informed consent from participants before data collection. Ethics clearance was obtained from 
Ethics Committee Universitas Pembangunan Nasional (UPN) Veteran Jakarta-Indonesia with the study protocol code of No: B/2082/VII/2019/KEPK.

\section{RESULTS}

Table 1 is the characteristics of the respondents' socio-demographic condition. Univariate analysis results show the proportion of male children under five years by $40,9 \%$ and female children under five years by $59,1 \%$. The proportion of the number of respondents with household members $\leq 4$ individuals is $58,4 \%$; $5-7$ individuals is $39,1 \%$; and $>7$ individuals is $2,5 \%$. Proportion of the number of respondents with household head occupation as farmers is $50,0 \%$; merchants is $13,3 \%$; civil servants is $3,3 \%$; factory labors is $17,5 \%$; drivers is $2,5 \%$; unemployed is $1,7 \%$; others is $11,7 \%$.
Furthermore, characteristics based on household head education are household head who are uneducated or did not graduate elementary school is $50,0 \%$; elementary school graduates is 9,2\%; junior high school graduates is $15,8 \%$; high school graduates are $21,7 \%$, and university graduates are $3,3 \%$. The proportion of households head age under 19 is $0,0 \%$; $19-35$ years old is $60,8 \%$; and $>35$ years old is $39,2 \%$. Meanwhile the proportion of mother aged $<19$ years old is $0,8 \%$; 19-35 years old is $82,5 \%$; and $>35$ years old is $16,6 \%$. Last, the proportion of mother who is uneducated or did not graduate elementary school is $50,0 \%$; elementary school graduates is $10,0 \%$; junior high school graduates is $18,3 \%$; senior high school graduates are $20,8 \%$, and university graduates are $0,8 \%$.

Table 1: Socio-demographic characteristics of the respondents $(n=120)$

\begin{tabular}{|c|c|c|c|c|c|c|}
\hline \multirow[t]{2}{*}{ Characteristics } & \multicolumn{2}{|c|}{$\begin{array}{l}\text { Indigenous } \\
\text { Children } \\
\text { (Suku Baduy) }\end{array}$} & \multicolumn{2}{|c|}{$\begin{array}{l}\text { Non-indigenous } \\
\text { Children }\end{array}$} & \multicolumn{2}{|c|}{ Total } \\
\hline & $\mathrm{n}$ & $\%$ & $\mathbf{N}$ & $\%$ & $\mathbf{N}$ & $\%$ \\
\hline \multicolumn{7}{|l|}{ Children under five years sex: } \\
\hline Male & 23 & 19.2 & 26 & 21.7 & 49 & 40.9 \\
\hline Female & 37 & 30.8 & 34 & 28.3 & 71 & 59.1 \\
\hline \multicolumn{7}{|l|}{ Number of family members: } \\
\hline$\leq 4$ & 41 & 34.2 & 29 & 24.2 & 70 & 58.4 \\
\hline $5-7$ & 19 & 15.8 & 28 & 23.3 & 47 & 39.1 \\
\hline$>7$ & 0 & 0 & 3 & 2.5 & 3 & 2.5 \\
\hline \multicolumn{7}{|l|}{ Work of the head of family: } \\
\hline Farmer & 60 & 50 & 0 & 0 & 60 & 50.0 \\
\hline Merchants & 0 & 0 & 16 & 13.3 & 16 & 13.3 \\
\hline Civil servants & 0 & 0 & 4 & 3.3 & 4 & 3.3 \\
\hline Factory labours & 0 & 0 & 21 & 17.5 & 21 & 17.5 \\
\hline Drivers & 0 & 0 & 3 & 2.5 & 3 & 2.5 \\
\hline Unemployed & 0 & 0 & 2 & 1.7 & 2 & 1.7 \\
\hline Others & 0 & 0 & 14 & 11.7 & 14 & 11.7 \\
\hline \multicolumn{7}{|l|}{ Education of the head of family: } \\
\hline $\begin{array}{l}\text { Uneducated or did not graduated elementary } \\
\text { school }\end{array}$ & 60 & 50 & 0 & 0 & 60 & 50.0 \\
\hline Elementary school & 0 & 0 & 11 & 9.2 & 11 & 9.2 \\
\hline Junior high school & 0 & 0 & 19 & 15.8 & 19 & 15.8 \\
\hline Senior high school & 0 & 0 & 26 & 21.7 & 26 & 21.7 \\
\hline University & 0 & 0 & 4 & 3.3 & 4 & 3.3 \\
\hline \multicolumn{7}{|l|}{ Age of the head of family (years): } \\
\hline$<19$ & 0 & 0 & 0 & 0 & 0 & 0.0 \\
\hline $19-35$ & 48 & 40 & 25 & 20.8 & 73 & 60.8 \\
\hline$>35$ & 12 & 10 & 35 & 29.2 & 47 & 39.2 \\
\hline \multicolumn{7}{|l|}{ Age of mother (years): } \\
\hline$<19$ & 0 & 0 & 1 & 0.8 & 1 & 0.8 \\
\hline $19-35$ & 56 & 46.7 & 43 & 35.8 & 99 & 82.5 \\
\hline $\begin{array}{l}>35 \\
\text { Education of mother: }\end{array}$ & 4 & 3.3 & 16 & 13.3 & 20 & 16.6 \\
\hline $\begin{array}{l}\text { Uneducated or did not graduated elementary } \\
\text { school }\end{array}$ & 60 & 50 & 0 & 0 & 60 & 50.0 \\
\hline Elementary school & 0 & 0 & 12 & 10 & 12 & 10.0 \\
\hline Junior high school & 0 & 0 & 22 & 18.3 & 22 & 18.3 \\
\hline Senior high school & 0 & 0 & 25 & 20.8 & 25 & 20.8 \\
\hline University & 0 & 0 & 1 & 0.8 & 1 & 0.8 \\
\hline
\end{tabular}


Figure 1: Nutritional status of children under five years among indigenous communities $(n=60)$ and nonindigenous communities $(n=60)$

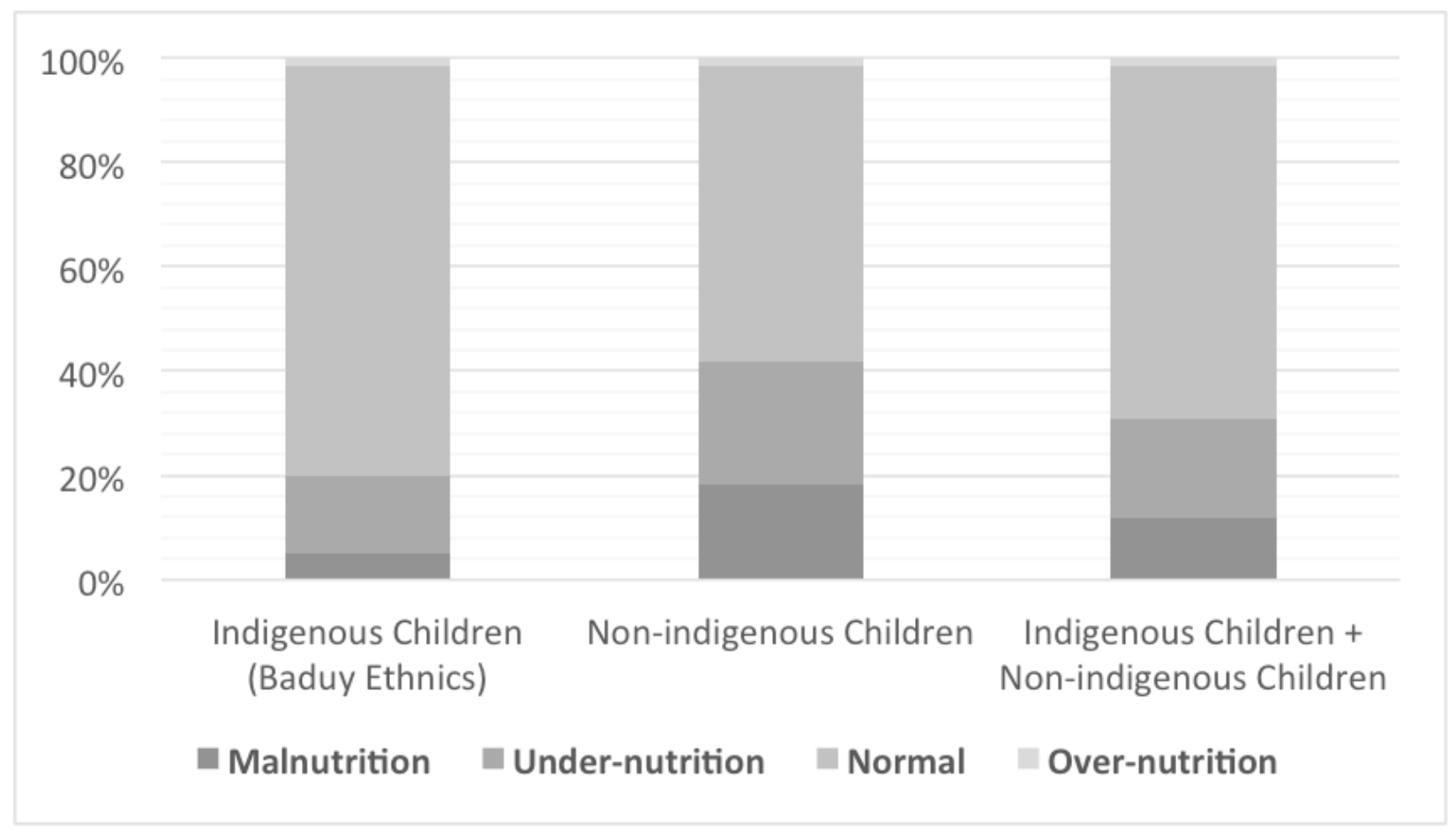

The results of children under five years of nutritional status measurement shows that children under five years from indigenous communities have better nutritional status compared to children under five years from nonindigenous communities. The outcomes for indigenous communities are as follows: malnutrition by $5,0 \%$; under-nutrition by $15,0 \%$; normal by $78,3 \%$; and over-nutrition by $1,7 \%$. Meanwhile, the prevalence in non-indigenous communities for malnutrition is $18,3 \%$; undernutrition is 23,3\%; normal is $56,7 \%$; and overnutrition is $1,7 \%$. Total prevalence in both communities for malnutrition is $11,7 \%$; undernutrition is $19,2 \%$; normal is $67,5 \%$; and overnutrition is $1,7 \%$.
Table 2 shows the results of bivariate testing that indicates the relation between children under five years of nutritional status and determinant factors. The results show that there are five variables with significant correlation, namely, household head education level $(P>0.001)$, ethnicity $(P=0.019)$, household head occupation $(P=0.019)$, household head age $(P=0.037)$, and source of drinking water $(P=0.019)$.

Multivariate test results show two variables have a significant influence in children under five years of malnutrition, namely, household head education with OR=0.120 (95\%C1: 0.021-0.675) and prenatal care in the fourth trimester with OR 9.890 (95\%C1: 1.349-72.531) (Table 3).

Table 2: Bivariate analysis of the nutritional status of children under five years in indigenous communities $(n=60)$ and non-indigenous communities $(n=60)$

\begin{tabular}{|c|c|c|c|c|c|c|c|}
\hline \multicolumn{3}{|c|}{ Variable } & \multicolumn{2}{|c|}{ Malnutrition* } & \multicolumn{2}{|c|}{ Normal } & \multirow[t]{2}{*}{$P^{\wedge}$} \\
\hline & & & $n$ & $\%$ & $n$ & $\%$ & \\
\hline \multirow{8}{*}{$\begin{array}{l}\text { Socio- } \\
\text { demographics }\end{array}$} & Community & Indigenous children & 13 & 21.7 & 47 & 78.3 & 0.019 \\
\hline & & $\begin{array}{l}\text { Non-indigenous } \\
\text { children }\end{array}$ & 26 & 43.3 & 34 & 56.7 & \\
\hline & Children under five & Male & 15 & 30.6 & 34 & 69.4 & 0.866 \\
\hline & years sex & Female & 24 & 33.8 & 47 & 66.2 & \\
\hline & Number of family & $\geq 5$ & 18 & 36.0 & 32 & 64.0 & 0.621 \\
\hline & members & $\leq 4$ & 21 & 30.0 & 49 & 70.0 & \\
\hline & Work of the head of & Farmer & 13 & 21.7 & 47 & 78.3 & 0.019 \\
\hline & the family & Non-farmer & 26 & 43.3 & 34 & 56.7 & \\
\hline
\end{tabular}




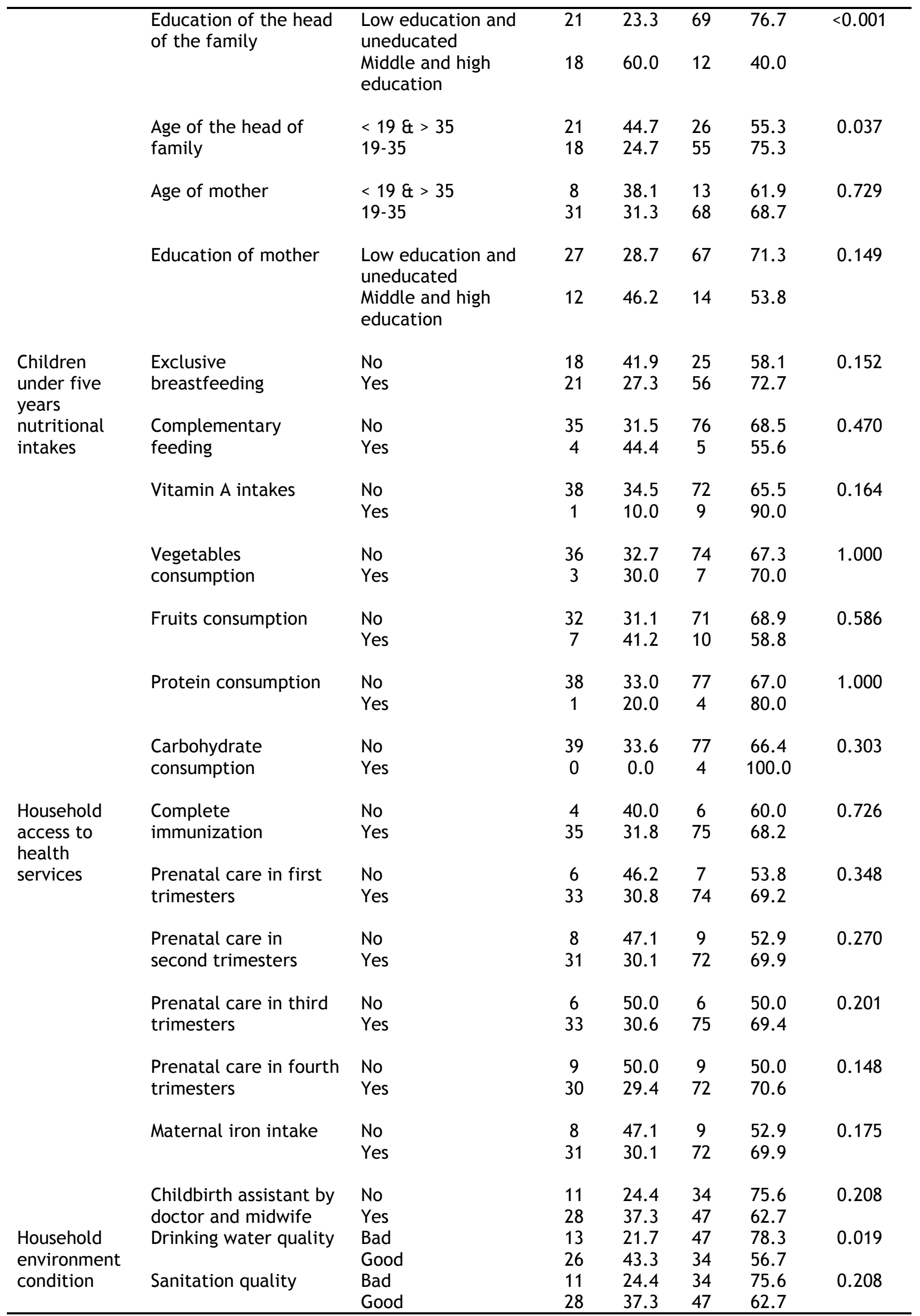

*Malnutrition is a combination of malnutrition, under-nutrition, and over-nutrition 
Table 3: Multivariate analysis of the nutritional status of children under five years in indigenous communities and non-indigenous communities $(n=120)$

\begin{tabular}{lcccccc}
\hline \multicolumn{1}{c}{ Variable } & B & Wald & Sig. & OR & \multicolumn{2}{c}{ Cl 95\% } \\
& & & & & Lower & Upper \\
\hline Community & -2.324 & 3.254 & 0.071 & 0.098 & 0.008 & 1.223 \\
Education of the head of family & -2.123 & 5.783 & 0.016 & 0.120 & 0.021 & 0.675 \\
Work of the head of family & -2.324 & 3.254 & 0.071 & 0.098 & 0.008 & 1.223 \\
Age of the head of family & 0.837 & 2.522 & 0.112 & 2.310 & 0.822 & 6.491 \\
Education of mother & 1.022 & 1.331 & 0.249 & 2.778 & 0.490 & 15.761 \\
Exclusive breastfeeding & 0.422 & 0.716 & 0.398 & 1.524 & 0.574 & 4.048 \\
Vitamin A intakes & 2.252 & 3.524 & 0.060 & 9.510 & 0.905 & 99.900 \\
Prenatal care in third trimesters & 0.862 & 0.660 & 0.416 & 2.368 & 0.296 & 18.952 \\
Prenatal care in fourth trimesters & 2.292 & 5.081 & 0.024 & 9.890 & 1.349 & 72.531 \\
Maternal iron intake & -0.176 & 0.052 & 0.819 & 0.839 & 0.186 & 3.781 \\
Childbirth assistant & 0.108 & 0.020 & 0.888 & 1.114 & 0.247 & 5.031 \\
Drinking water quality & -2.324 & 3.254 & 0.071 & 0.098 & 0.008 & 1.223 \\
Sanitation quality & 1.451 & 1.811 & 0.178 & 4.265 & 0.516 & 35.283 \\
\hline
\end{tabular}

\section{DISCUSSION}

The Government of Indonesia has included the program to resolve children under five years of malnutrition in The National Medium-term Development Program (RPJMN) 2020-2024, targeting the reduction of stunting numbers in children under five years from $30,8 \%$ to $19,0 \%$ and wasting from $10,2 \%$ to $7,0 \%$. There are two prioritized agendas, that are (1) developing a nutrition and growth security system by providing nutritional intake guarantees since pregnancy, improving family parenting as well as clean water and environmental sanitation facilities; and (2) accelerating stunting reduction by increasing the effectiveness of specific interventions, expanding and sharpening integrated nutrition-sensitive intervention ${ }^{25}$.

It is understood that tackling the problem of malnutrition must be integrated and comprehensive in all communities, particularly those with a higher risk of experiencing malnutrition. This will be a challenge for the government for accurate data and information regarding determinant factors of children under five years of malnutrition in each community are needed, while studies in those issues are still limited. This especially applies to the indigenous community that tends to be marginalized in the national health service system in many countries $^{26,27}$.

This research has resulted in several findings that are important to be discussed to find a solution for malnutrition in two communities, which are indigenous community and the non-indigenous community. First, we obtained different results from several studies in other countries regarding infant malnutrition problems in indigenous communities that conclude children from indigenous communities have a high risk of suffering from malnutrition. For instance, in Brazil, the First National Survey of Indigenous People's Health and Nutrition found $6 \%$ of the indigenous children are underweight and $26 \%$ are stunted ${ }^{28,29}$. In Australia, about $10-14 \%$ of indigenous children suffer from under-nutrition ${ }^{30}$. In Peninsular Malaysia, $49 \%$ indigenous children are underweight and $64 \%$ are stunted ${ }^{31}$. In Peru, $49 \%$ indigenous children are found stunted, $20.4 \%$ underweight, and $4.0 \%$ wasting ${ }^{32}$. However, in this study, children under five years from Suku Baduy have better nutritional status compared to the ones from indigenous communities.

This finding becomes interesting because we witnessed the way of life and the source of good nutrition in the Suku Baduy tribe contribute greatly the community quality nutrition. The tribe's ability in preserving biodiversity makes local food rich in nutrients and abundant. The tribe is never short of food, which is different from non-indigenous communities that are vulnerable to food shortages. Therefore, maintaining the culture of preserving nature and developing local food production in Suku Baduy is one of the strategies to improve the community's nutritional status.

Second, there are two determinant factors causing children under five years of malnutrition in both communities in this study, namely, household head education level and antenatal care in the fourth trimester. The first factor always becomes the primary cause of malnutrition in several studies ${ }^{14,33}$. Education is key to parent's knowledge of balanced nutrition needed for children's growth and development ${ }^{34}$. The lack of knowledge in balanced nutrition will make parents serve their children with poor nutrition and bad diet ${ }^{35}$. The implication is infants will lack a good source of nutrition for their growth and development process.

The second factor is related to maternal health access. The key to children's growth and development depends on the first 1000 days of life and this starts from pregnancy 36,37 . Good nutritional intakes and routine check-ups during pregnancy are necessary. Prenatal care is important to examine fetal health condition and 
to measure its growth and development ${ }^{38}$. In communities with minimal health access, pregnant women rarely see health workers for prenatal care $^{39}$. As a result, there is a risk of low birth weight that results in malnutrition ${ }^{9,10}$. Thus, increasing maternal health access is key to resolve the problems of malnutrition.

\section{CONCLUSION}

The results of this study can be a reference for the Government of Indonesia to design malnutrition improvement programs, especially in indigineous communities and urban communities. Where the program has become a priority agenda in the health sector in the next five years in Indonesia. Specifically, in the two communities that were the object of this study, it is necessary to increase community knowledge of balanced nutrition in infants and increase maternal health access to curb malnutrition problems in children under five years.

\section{ACKNOWLEDGMENTS}

We are grateful to the Lebak District Government and Kenakes Village Government, who both gave priceless contribution in supporting this study, particularly during the data collection. We also would like to thank the Research and Community Service Institution of Universitas Pembangunan Nasional (UPN) Veteran Jakarta-Indonesia and Ministry of Research, Technology and Higher Education of the Republic Indonesia for their institutional support throughout this study.

\section{REFERENCES}

1. Silva ID and Sumarto S. Child Malnutrition in Indonesia: Can Education, Sanitation and Healthcare Augment the Role Income? Journal of International Development, Volume 30, Issue 5, July 2018. doi: $10.1002 /$ jid. 3365 .

2. Beal T, Tumilowicz A, Sutrisna A et al. A Review of Child Stunting Determinant in Indonesia. Maternal Child Nutrition. 2018 October; 14(4): e12617. doi: $10.1111 / \mathrm{mcn} .12617$.

3. Ministry of Health Republic of Indonesia. Riset Kesehatan Dasar (Basic Health Research) 2018. Available from: http: / / www.kesmas.kemkes.go.id/asse ts/upload/dir_519d41d8cd98f00/files/H asil-riskesdas-2018_1274.pdf

4. Global Nutrition Report. Malnutrition Burden: Singapore Nutrition Profile. Available from: https: //globalnutritionreport.org/medi a/profiles/v1.9.7/pdfs/singapore.pdf
5. Global Nutrition Report. Malnutrition Burden: Thailand Nutrition Profile. Available from: https: / /globalnutritionreport.org/medi a/profiles/v1.9.7/pdfs/thailand.pdf

6. Global Nutrition Report. Malnutrition Burden: Brunei Darussalam Nutrition Profile. Available from: https: //globalnutritionreport.org/medi a/profiles/v1.9.7/pdfs/bruneidarussalam.pdf

7. Global Nutrition Report. Malnutrition Burden: Malaysia Nutrition Profile. Available from: https: //globalnutritionreport.org/medi a/profiles/v1.9.7/pdfs/malaysia.pdf

8. Global Nutrition Report. Malnutrition Burden: Vietnam Nutrition Profile. Available from: https: / /globalnutritionreport.org/medi a/profiles/v1.9.7/pdfs/viet-nam.pdf

9. Derso T, Tariku A, Biks GA et al. Stunting, Wasting and Associated Factors Among Children Aged 6-24 Months in Dabat Health and Demographic Survaillance System Site: A Community Based Cross-sectional Study in Ethiopia. BMC Pediatr 17(1), 2017: 96. doi: $10.1186 / s 12887-017-0848-2$.

10. Ortiz J, Camp JV, Wijaya S et al. Determinant of Child Malnutrition in Rural and Urban Ecuadorian Highlands. Public Health Nutrition 17(9), 2014. 2122-2130. doi: $10.1017 / \mathrm{S} 1368980013002528$.

11. Kattula D, Sarkar R, Sivarathinaswamy P, et.al. The First 1000 Days of Life: Prenatal and Postnatal Risk Factors for Morbidity and Growth in A Birth Cohort in Southern India. BMJ Open 4. 2014; e005404: 1-10.

12. Hanifa L, Wulansari R, Meiandayati $R$ et al. Stunting Trends and Associated Factors among Indonesia Children Aged 0-23 Mounth: Evidence from Indonesia Family Life Surveys (IFLS) 2000, 2007 and 2014. Mal J Nutr 24(3), 2018: 315322.

13. Ramirez-Luzuriaga MJ, Belmont $P$, Waters WF et al. Malnutrition Inequalities in Ecuador: Differences by Wealth, Education Level and Etnicity. Public Health Nutrition 23(1), 2019. doi: 10.1017/S1368980019002751.

14. Abuya BA, Ciera J, Murage EK. Effect Mother's Education on Childs Nutritional 
Status in The Slums of Nairobi. BMC Pediatrics 12: 80. 2012. doi: 10.1186/1471-2431-12-80.

15. Rachmi CN, Agho KE, Li $M$ et al. Stunting, Underweight and Overweight in Children Aged 2.0-4.9 Years in Indonesia: Prevalence Trends and Associated Risk Factors. PLoS ONE, 2016, 11(5) e0154756. doi: $10.137 /$ journal.pone. 0154756 .

16. Jones KD, Thitri J, Ngari M, and Berkley JA. Childhood Malnutrition: Toward an Understanding of Infections, Inflammation, and Antimicrobials. Food Nutr Bull. 2014 Jun: 35(20): S64-S70. doi: $10.1177 / 15648265140352 S 110$.

17. Walson JL and Berkley JA. The impact of Malnutrition on Childhood Infections. Curr Opin Infect Dis. 2018 Jun; 31(3): 231-236.

doi:

10.1097/QCO.0000000000000449.

18. Otsuka $Y$, Agetika L et al. Risk Factors for Under-nutrition and Diarrhea Prevalence in an Urban Slum in Indonesia: Focus on Water, Sanitation, and Hygiene. Am J Trop Med Hyg. 2019 Mar; 100(3): 727-732. doi: 10.4269/ajtmh.18-0063.

19. Rah JH, Cronin AA et.al. Household Sanitation and Personal Hygiene Practices are Associated with Child Stunting in Rural India: A Cross-sectional Analysis of Surveys. BMJ Open. 2015; 5(2): e005180. doi: 10.1136/bmjopen2014-005180.

20. Statistics Indonesia. Population Cencus 2010. Jakarta. Statistics Indonesia.

21. Senoaji G. Masyarakat Baduy, Hutan dan Lingkungan (Baduy Community, Forest and Environment). Jurnal Manusia dan Lingkungan, Vol. 17 No. 2, 2010: 113123. doi: $10.22146 / j m l .18710$.

22. Arisetyawan A, Suryadi D, Herman T et al. Study of ethnomathematics: a lesson from Baduy culture. International Journal of Education and Research, Vol. 2 No. 10, 2014: 681-688.

23. Purba AS, Hufad A, Negara CP et al. The implication of Baduy Dalam Tribe's Closure on Indonesia's Rank in The World Economic Forum. Advances in Social Science, Eductaion and Human Research, Volume 251, 2018: 430-423.
24. World Health Organization (WHO). Levels and Trends in Child Malnutrition. Geneva: WHO. 2012.

25. National Development Planning Agency of Indonesia. Rencana Pembangunan Jangka Menengah Nasional (National Medium-term Development Plan) 20202024. Available from: https: / /www.bappenas.go.id/files/rpj $\mathrm{mn} /$ Narasi\%20Rancangan\%20RPJMN\%202 020-2024.pdf

26. Matthews R. The Cultural Erosion of Indigenous People in Health Care. CMAJ. 2017 Jan 16; 189(2): E78-E79. doi: $10.1503 / \mathrm{cmaj} .160167$.

27. Horril T, McMilan DE, Schultz ASH et al. Understanding Access to Healthcare among Indigenous Peoples: A Comparative Analysis of Biomedical and Postcolonial Perspectives. Nursing Inquiry. 2018 Jul; 25(3): e12237. doi: $10.1111 /$ nin. 12237 .

28. Horta BL, Santos RV, Welch JR et al. Nutritional Status of Indigenous Children: Findings from The First National Survey of Indigenous People's Health and Nutrition in Brazil. International Journal for Equity in Health 12:23, 2013. p.1-33.

29. Coimbra CEA, Santos RV, Welch JR et al. The First National Survey of Indigenous People's Health and Nutrition in Brazil: Rationale, Methodology, and Overview of Results. BMC Public Health 13. 2013.

30. Burn J, Thomson N. Review of Nutrition and Growth among Indigenous Peoples. Australian Indigenous Health Info Net. 2008. Available from: http: / /www.healthinfonet.ecu.edu.au/ health-risks/nutrition/reviews/ourreview (access November 2019).

31. Wong CY, Zalilah MS, Chua EY et al. Double-burden of Malnutrition among The Indigenous Peoples (Orang Asli) of Peninsular Malaysia. BMC Public Health 15:680. 2015. p.1-9. doi: $10.1186 / \mathrm{s} 12889-0152058 x$.

32. Anticona C, Sebastian MS. Anemia and Malnutrition in Indigenous Children and Adolescents of The Peruvian Amazon in a Context of Lead Exposure: A Crosssectional Study. Global Health Action 7:1, 22888. 2014. doi: 10.3402/gha.v7.22888.

33. Ramirez-Luzuriaga MJ, Belmont $P$, Waters WF et al. Malnutrition 
Inequalities in Ecuador: Differences by Wealth, Education Level and Etnicity. Public Health Nutrition 23(1). 2019. doi: $10.1017 /$ S1368980019002751.

34. Kuhnlein H, Receveur O, Soueida R et al. Unique Patterns of Dietary Adequacy in Three Cultures of Canadian Arctic Indigenous Peoples. Public Health Nutrition 11(4), 349-360. 2007. doi: $10.1017 / \mathrm{S} 1368980007000353$.

35. Emamian $M H$, Fateh $M$, Gorgani $N$ et al. Mother's Education is The Most Important Factor in Socio-economic Inequality of Child Stunting in Iran. Public Health Nutrition 17(9), 2013. 2010-2015. doi: $10.1017 / \mathrm{S} 1368980013002280$.

36. Pietrobelli A, Agosti M, MeNu Group. Nutrition in The First 1000 Days: Ten Practices to Minimize Obesity Emerging from Published Science. International Journal of Environmental Research and Public Health. 2017, 14, 1491. doi: 10.3390/ijerph14121491.
37. Schwarzenberg SJ, Georgieff MK, Committee on Nutrition. Advocacy for Improving Nutrition in The First 1000 Days to Support Childhood and Adult Health. Pediatrics, February 2018, 141(2) e20173716. doi: 10.1542/peds.2017-3716.

38. Kuhnt J, Vollmer S. Antenatal Care Services and Its Implications for Vital and Health Outcomes of Children: Evidence from 193 Survey in 69 Lowincome and Midlle-income Countries. BMJ Open (7): e017122. 2017. doi: 10.1136/bmjopen-2017-017122.

39. Hamel C, Enne J, Omer $\mathrm{K}$ et al. Childhood Malnutrition is Associated with Maternal Care during Pregnancy and Childbirth: A Cross-sectional Study in Bauchi and Cross River States, Nigeria. J Public Health Res 4(1):408. 2015. doi: $10.4081 /$ jphr.2015.408. 